\title{
Degree Celsius
}

National Cancer Institute

\section{Source}

National Cancer Institute. Degree Celsius. NCI Thesaurus. Code C42559.

A unit of temperature of the temperature scale designed so that the freezing point of water is 0 degrees and the boiling point is 100 degrees at standard atmospheric pressure. The current official definition of the Celsius sets $0.01 \mathrm{C}$ to be at the triple point of water and a degree to be $1 / 273.16$ of the difference in temperature between the triple point of water and absolute zero. One degree Celsius represents the same temperature difference as one Kelvin. 